\title{
ELWIRA BUSZEWICZ
}

Uniwersytet Jagielloński, Kraków

\section{SEMIOTICS OF OLD AGE IN POLISH NEO-LATIN POETRY. SAMBORITANUS, COCHANOVIUS, TRETER, SARBIEVIUS, INES}

\begin{abstract}
Buszewicz Elwira, Semiotics of Old Age in Polish Neo-Latin Poetry. Samboritanus, Cochanovius, Treter, Sarbievius, Ines (Semiotyka starości w polskiej poezji nowołacińskiej. Grzegorz z Sambora, Kochanowski, Treter, Sarbiewski, Ines).
\end{abstract}

The main aim of this paper is to analyze several early-modern Neo-Latin poems written by Polish authors; the poems deal (in different ways) with old age. The poets undertake a kind of intertextual game with the reader, applying various stereotypes and clichés. On can speak about a "semiotic landscape" of old age. The authors taken into consideration are Jan Kochanowski, Grzegorz of Sambor, Thomas Treter ( $16^{\text {th }}$ century) and Maciej Kazimierz Sarbiewski, Albert Ines ( $17^{\text {th }}$ century).

Keywords: Neo-Latin poetry; old age in literature; Jan Kochanowski; Gregory of Sambor; Thomas Treter; Maciej Kazimierz Sarbiewski; Albert Ines.

I.

Before I pass to my particular subject, I feel obliged to explain what kind of semiotics I mean.

It is not my intention to engage in a scholarly categorization, especially in the present era, when semiotic studies have become popular in many countries and are used in many disciplines by scholars dealing not only with literature or culture, but also with sociology ${ }^{1}$ or even artificial intelligence. My aim is to focus on the most basic meaning close to the broadest definition made by Umberto Eco: "semiotics is concerned with everything that can be taken as a sign," where a sign is "everything that, on the grounds of a previously established social convention, can be taken as something standing for something else." As Daniel Chandler emphasizes, "signs take the form of words, images, sounds, gestures and objects." ${ }^{4}$ My semiotic approach will be related to intertextuality ${ }^{5}$ and will

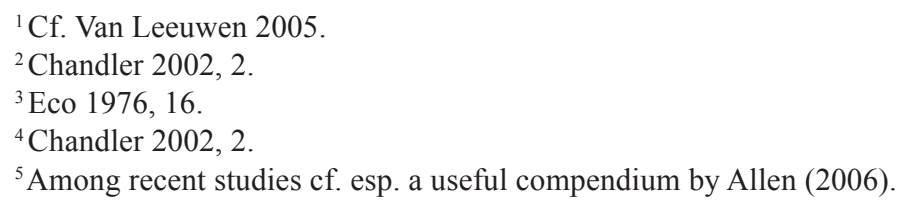


be also intersemiotic, which is to mean that textual signs refer to some other "sign-systems" involving new meanings or new levels of significance. ${ }^{6}$

I drew the inspiration from an article by Jerzy Danielewicz, published in 1975 (Pejzaż semiotyczny w "Pieśniach" Horacego). ${ }^{7}$ The author puts forward the notion that Horace's images of nature have a special structure, suggesting a new meaning connected with exhortation or advice to an addressee. He discusses, for example, the stanza:

$$
\begin{aligned}
& \text { Quo pinus ingens albaque populus } \\
& \text { umbram hospitalem consociare amant } \\
& \text { ramis, quid oblique laborat } \\
& \text { lympha fugax trepidare rivo? }
\end{aligned}
$$

[To what purpose do the huge pine and the white poplar

love to weave their branches into hospitable shade?

And why does the rushing stream twist and strain

as it bustles along? ${ }^{9}$

He emphasizes that the text immanently contains elements of Epicurean philosophy in the form of a suggestion developed in next lines. My intention is to go further in analysing such semiotic landscapes, according to the hints of William Anderson and many other scholars. In their interpretation the Horatian landscapes not only have their "modal frames", but also are in certain ways "personalized." If we take into consideration the stanza quoted above, the trees to some extent represent the humans. ${ }^{10}$

The use of the words consociare amant, is meant to give a hint which Horace seldom omits when his theme is the brevity of life, i.e., that love-making as well as drinking should not be neglected. ${ }^{11}$ Similarly one can find the lympha fugax in the following lines and it is hard not to agree that "the laboring stream, trembling along in its devious course, suggests the transience of all human efforts." 12

After these initial remarks I shall proceed to an analysis of several Polish Neo-Latin poems, focusing on a 'semiotic' image of old age. I have chosen those texts in which some crucial archetypes ${ }^{13}$ appear, sketched more or less sharply:

${ }^{6}$ Semiotics, as Chris Baldick $(1990,201)$ defines it, is "the systematic study of signs, or, more precisely, of the production of meanings from sign-systems, linguistic or non-linguistic."

${ }^{7}$ Danielewicz 1975, 297-301.

${ }^{8}$ Hor. Carm. II 3 9-12.

${ }^{9}$ Horace 2000, 58.

${ }^{10}$ Anderson 1999, 122.

${ }^{11}$ Wilkinson 1951, 129.

${ }^{12}$ Commager 1962, 284

${ }^{13}$ I mean some archetypal patterns, deeply embedded in human consciousness, which recur throughout the history of literature; as part of the language system they become verbal stereotypes (clichés). 
first, an old mother as a kind of matron, next - an old father, evoking Anchises's figure (of course that of a feeble, aged man, not of a ghostly mentor), and finally - an old lascivious woman, owing very much to Horace. But there are also some $17^{\text {th }}$ century poems which I made the subject of my reflection, though they contain only a foggy, gnomic landscapes of old age, very much in Horatian manner.

To begin with, we may discuss a poem of Vigilantius Gregorius Samboritanus, rather a less known Renaissance Latin poet (c. 1520-1573). ${ }^{14}$ The man of plebeian origin, son of Gregory, a shoemaker of Sambor, and Anna, a village woman, made a teaching career from a post of professor of humaniora at provincial schools to a Collega Maius, that means ordinary professor at the Jagiellonian University; at the end of his life he was a lecturer of Holy Scripture. He composed mainly occasional and panegyric verses, but the long elegy Parentes differs in it's contents from usual Gregory's practice. The narrator, representing the poet, recalls the moment of his mother's death, at which he was present. He had paid her a visit after a year of absence. A shadowy phantom of death is present at the very beginning of the tale, which is periphrastic and allusive:

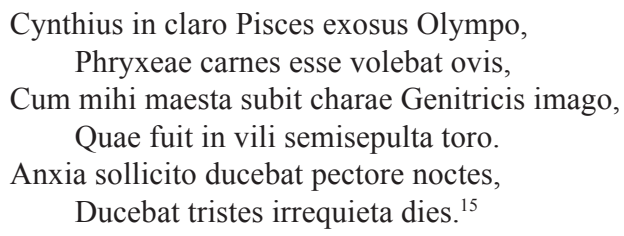

[Cynthius, having repulsed Pisces in the bright sky, / wanted to take the flesh of Phryxean sheep, / when I saw in my mind my dear mother's worried face, / who was half-buried in a vile bed. / She was spending her nights anxiously, with solicitous heart; / She was spending her days unquietly. $]^{16}$

The poet's choice of words seems to echo Ovidian poetry. The mother, as imagined by the narrator, lies in a poor bed, which sharply contrasts with the image of Ovid's young mistress from Amores, who rests in a purple bed. ${ }^{17}$ The epithet semisepulta may have also an Ovidian provenance (used as the neuter plural in Heroides and evoking the panorama of the dying Troy. ${ }^{18}$ The epithet inrequietus is, similarly, an Ovidian invention, ${ }^{19}$ employed in the first book of Metamorphoses and concerning the Enipeus river. The epithet used by Samboritanus seems to be a hypallage, which refers to not so much the dying mother's feelings as the poet's

\footnotetext{
${ }^{14}$ Buszewicz 2011, 13-14.

${ }^{15}$ Samboritanus $1562, \mathrm{Br}$.

${ }^{16}$ If not marked otherwise, translations are my own.

${ }^{17} \mathrm{Cf}$. Ov. Am. I 1420.

${ }^{18}$ Cf. Ov. Her. 1. 55: "Semisepulta virum curvis feriuntur aratris / ossa, ruinosas occulit herba domus."

${ }^{19}$ Anderson 1997, 205. Cf. Ov. Met. II.579: "populifer Sperchios et inrequietus Enipeus."
} 
own anxiety. In the same way the expression sollicito pectore, connected with the old mother, may describe rather the narrator's disquiet (as sometimes is the case in love poetry). ${ }^{20}$ But the poet, creating his literary mosaic, may follow also Horace's admonition from Ars poetica: "I bid the artist, trained in representation, to reflect on exemplars of life and character and to bring us living voices from that source." ${ }^{21}$ Describing his mother he tells us that she was poor and affected with disease, debilitated (as we know from another passage of the elegy, she had had ten children, five sons and five daughters), and old. "Martius - as the poet says - esse parum senibus solet esse benignus. / Multos hic solitus condere mensis humo est." 22 ["March is not wont to be benign to old persons. This month used to bury many of them under the ground"']. It is the experience, the common, practical knowledge, that emerges from poetic discourse - a significant number of people died during the period of famine, the "hungry gap" of early spring.

The very moment of Anna's death, although painted with rhetorical colours, reveals rather a pessimistic condition of the old woman. As the poet confesses, both his mother and he were anticipating her death, and his mother's hopeless condition was a reason which convinced the son that death would be the best solution. The narrator has a long talk with himself and discusses whether it is possible and morally good to wish for a parent's death. But to wish for a longer life for the suffering woman means to wish her more pain and, in fact, to delay a moment of her entrance into eternal happiness:

Sic sine fine suo viveret aegra malo?

Sic sua, sic semper lugerat damna suorum?

Nec requiem tantis posset habere malis?

[Could she live forever in this poor condition? / Could she always weep for her loss? For the loss of her family? / Would she never find relief from these miseries?]

The poet makes us hear his mother's voice of prayer begging God for death:

'Tolle, Deus, puram putrido de corpore mentem'

Dixit; 'ab hoc animam tolle carcere meam.

Quando corporeae iam spes est nulla salutis.

Quando venit morbo nulla medela meo,

Accipe me miseram, miserae miserere precantis,

Accipe demissa supplicis aure preces'.

${ }^{20}$ Cf. Landino's Xandra III 4, 121-122 in: Cristoforo Landino, Poems, transl. Mary P. Chatfield (Cambridge, Mass.: Harvard University Press, 2008), 162: "Excitor infelix et iam praesaga future / Mens mihi sollicito pectore concutitur". In Mary Chatfield's translation, 163: "Sorrowfully I awake, and my mind, full of foreboding / already is stricken in my anxious breast."

${ }^{21}$ Hor. Ars 317-318: "respicere exemplar vitae morumque iubebo / doctum imitatorem et vivas hinc ducere voces"; transl. Leon Golden, in: Horace 1995, 17.

${ }^{22}$ Samboritanus 1562, Br. 
['Oh God,' she said. 'Take the pure mind from the putrid body, / Release my soul from this prison, / Now, when there is no hope for physical health, / When there is no medicine for my disease. / Receive me, miser as I am, have mercy on such a miser supplicant, / Incline your ear and receive the prayers of a suppliant.]

God hears the prayer and the old woman, completely reconciled with fate, passes from life into death. Modern readers may think here of Gauguin's painting Where Do We Come From? What Are We? Where Are We Going?, especially of the section representing an old woman who is very close to death and seems to accept everything. ${ }^{23}$

As for male old age, we may discover in Samboritanus' poetry some decidedly more optimistic depiction. In the Theoresis secunda, mentioned above, we find a memory of the poet's father, deceased a year before his wife. The man, endowed with corporeal forces, being 80 years old, blind or almost blind, three months before his death decided to visit his son in Lvov. He intended to march from Sambor to Lvov on foot and after passing two Polish miles in this way, was carried to his destination. Having spent a month with his son, the old man returned to Sambor, where he died calmly, reciting the Litany of All Saints. ${ }^{24}$ This heroic figure would have stupefied even Cicero's Cato Major. ${ }^{25}$

Among Samboritanus' descriptions of male old age we can also find a brief portrait of a scholar from Krakow, professor Michael of Wiślica - once a famous astronomer, who found comfort in a kind of humanist anamnesis - he repeats the poems known by heart and is delighted to discuss them. Here the poet seems to mirror the Ciceronian paradigm of old age: ${ }^{26}$

${ }^{23}$ Iconographic representations from early modern period are widely discussed in Borewicz (2016, V, VII), especially anus pia (327).

${ }^{24}$ Samboritanus 1962, B3v.-B4r.

${ }^{25}$ Cf. Cic. De sen. X. 32: "Quartum ago annum et octogesimum; vellem equidem idem possem gloriari quod Cyrus, sed tamen hoc queo dicere, non me quidem eis esse viribus, quibus aut miles bello Punico aut quaestor eodem bello aut consul in Hispania fuerim aut quadriennio post, cum tribunus militaris depugnavi apud Thermopylas M'. Glabrione consule; sed tamen, ut vos videtis, non plane me enervavit, non adflixit senectus." [Cf. Cicero 1909, 57: "I am in my eighty-fourth year. I could wish that I had been able to make the same boast as Cyrus; but, after all, I can say this: I am not indeed as vigorous as I was as a private soldier in the Punic war, or as quæstor in the same war, or as consul in Spain, and four years later when as a military tribune I took part in the engagement at Thermopylae under the consul Manius Acilius Glabrio; but yet, as you see, old age has not entirely destroyed my muscles, has not quite brought me to the ground."]

${ }^{26} \mathrm{Cf}$ Cic. De sen. X 33: "Cursus est certus aetatis et una via naturae, eaque simplex, suaque cuique parti aetatis tempestivitas est data, ut et infirmitas puerorum, et ferocitas iuvenum et gravitas iam constantis aetatis et senectutis maturitas naturale quiddam habeat, quod suo tempore percipi debeat" [Cicero 1909, 57: "The course of life is fixed, and nature admits of its being run but in one way, and only once; and to each part of our life there is something specially seasonable; so that the feebleness of children, as well as the high spirit of youth, the soberness of maturer years, and the ripe wisdom of old age - all have a certain natural advantage which should be secured in its proper season."] 
Hic pater est Michael, longos provectus in annos

Visliciae Michael nomen amorque suae;

Astronomus fuerat florente peritus in aevo,

Nunc illum tristem longa senecta facit.

Carminibus vatum recreat se saepe legendis

Quae repetens memori plurima mente tenet. ${ }^{27}$

[There is Father Michael, far along in his age, / Beloved of Wiślica, from which he took his name; / In his vigorous age he was a skilful astronomer / And now his long senectitude makes him sad. / He regains the vigour often reciting poems, / Which he repeats and knows many of them by heart]

Now, as mentioned above, I would like to discuss some Latin poems of Jan Kochanowski. I deliberately pass over the epigram Epitaphium Maronidis, which is a paraphrase of Leonidas of Tarent from Greek Anthology (VII, 455) and has its vernacular counterpart in the collection of Fraszki [Trifles] (III 55, Nagrobek Rozynie) ${ }^{28}$ However, it seems worth a minute to look at the epitaph and notice that the deceased remains thirsty after her own death (which is a commonplace), and that her dead body is poetically reduced to the bones (ossa) ${ }^{29}$ But we can find a more impressive image of female old age in the final lines of the last elegy in Book Three:

Sed quaecumque olim damnis ditescet amantum,

Illas igne rapi vindice ploret opes.

Tum neque curet aqua sedare incendia quisquam,

Sed praedam medio raptor ab igne petat.

Atque aliquis flammam spectans furumque rapinas,

Artibus haec iuret parta fuisse malis.

Haec mala mox aliis cumulent fata aspera damnis,

Angat eam longa fracta iuventa die.

Angant et rugae candensque aetate capillus,

Nec quidquam viridi quem nuce tinguat anus.

Blanditias primaeque imitetur verba iuventae,

Sed quae sint canae non satis apta comae.

Illa puellarum choreis sese iungerat ultro,

Illa putet cantus posse placere suos.

Illam collatis iuvenes clam nutibus, illam

Et virgo, et simplex rideat usque puer.

Clam nunc, deinde palam; donec dediscat amari,

${ }^{27}$ Samboritanus 2011,140.

${ }^{28}$ Cf. Kochanowski 1967, 226.

${ }^{29} \mathrm{Cf}$. Kochanowski 1584, 152 :"Vini pernicies iacet hic annosa Maronis, / Summa super cuius stat monumenta calix. / Non illa aut natos sub terra inopemve maritum, / Sed vacuum infelix flet super ossa scyphum" ["Here lies an aged destructress of wine, Maronis, and there is a cup on her tomb. She is weeping neither over her surviving children nor for her poor husband, but over the empty cup which is standing over the bones"]. Recently published studies on the cultural history of the old drunken crone see Borowicz, Hobot, Przybylska 2016. 
In cineremque abeat fax vetus illa suum.

Iam tum non timeat petulantes ianua moechos,

Ianua florum expers et peritura siti.

Illaque iam dominae feriat vox rarior aurem:

„Dormire, heu, saxum, me pereunte, potes."

Tum vero curam cognatas vertat ad artes

Et facibus castis insidietur anus.

Gaudiaque ignotos ad mutua cogat amantes

Et praestet turpem culpae alienae operam.

Atque ubi iam vires aetas absumpserit omnes,

Emendicati munera panis edat.

Iamque adeo et morbi, veneris monumenta nefandae

Et celata diu Parthenopea lues,

Ossibus emergat perque omnes saeviat artus

Impune, et medicae rideat artis opem.

$\mathrm{Nec}$, nisi post longos mors cunctabunda dolores,

His miserum solvat corpus anile malis.

Sed tantum corpus: nam sontem Cerberus umbram

Ultor aget coecas trans Acherontis aquas,

In pertusum ubi vas lympham ferat, ut pote cuius

In vita nunquam est exsatiata fames.

His ex aequo omnes diris oneramus avaras,

Ast a te, o mea lux, sint ea fata procul.

Sint procul; idque adeo, si in me nil tu quoque peccas

Sive etiam peccas, sit tibi mitis Amor. [11. 59-100] ${ }^{30}$

[But may anyone who would get rich, harming her lover, / Weep for her wealth consumed by fire. / Then may no one fight the fire with water, / But rather may try to take his booty from it. / May another one, watching the flames and plundering thieves, / Swear that the fortune was achieved through evil arts. / After this cruel fate, may the damage become even worse: / After her youth is over, may she be old for a long time. / May her wrinkles annoy her, and grey hair - / (the aged woman will be unable to dye it even with the green nut shells.) / May she imitate some charming words of youth, / Inadequate to white hair. / May she join spontaneously the dancing maidens, / May she be convinced that her singing is pleasant. / May young men mock at her giving secret signs, / May any maiden and even any simple boy mock her - / At first secretly, then openly; finally, may she forget to be loved; / May this old torch go in its ashes. / May the door not be afraid of petulant adulterers, / The door without flower garlands, the door dying of thirst. / May the lady's ear seldom be attacked by a voice: / „Oh you stone! You can sleep while I am dying". / Then, may the hag devote herself to related arts, / May she deceive the innocent with her torches. / May she force some unknown lovers to experience mutual delights, / May she contribute to another's fault. / And when all her strength is consumed by age, / May she eat beggar's bread. / And then, may the diseases, memorials of abominable Venus / Including the (long-time hidden) Neapolitan malady / Emerge out of the bones and attack unpunished the whole body, / Deriding the medical art and aid. / After long pains may a dilatory death / Release this poor senile flesh from these miseries. / But only the flesh. As to the guilty shadow, / Cerberus - an avenger - may drive it through waters of Acheron, / May it carry water in a perforated vessel as someone / Whose hunger was never satiated on the Earth. / We burden equally all avaricious women with this malediction, / But may such fate, darling,

\footnotetext{
${ }^{30}$ Kochanowski 1584, 99-101.
} 
be far from you. / May it be far from you, or rather if you have no faults against me / Or even if you have any, may Amor be kind to you.]

A curse is put on any dishonest woman, whose fortune is a fruit of abusing her lovers' wealth. It might be called a "litany" of evil wishes, the first of which is a huge flame, consuming all her possessions. The next maledictions build a very abominable vision of her old age - not only the wrinkles and badly coloured grey hair, but also indecent behaviour, dancing, seducing youths, all of which is to make her an object of mockery. ${ }^{31}$ The initial conflagration meets the allegory of extinct torch which will be totally powerless as soon as its flame will turn it to ashes. Discourse of paraclausithyron, evoked immediately, stresses an erotic dimension of the "door" (ianua), ${ }^{32}$ (in this case it is the door "without flower garlands" and eventually devoid of any lust). Subsequent maledictions predict a miserable future of this ungrateful lover: she should be a procuress or a beggar, infected, to complete the picture, with many diseases, including syphilis (of course, an incurable one). The curse contains also post mortem damnation although the dead body will not suffer any pain, the soul has to share the fate of the Danaids, whose image refers to a limitless lust as the retribution for sexual rejection (the rule of contrapasso ${ }^{33}$ in Dante's Hell can be reminded here).

We also find an image of an ageing woman in another of Kochanowski's poem, very Horatian (both in theme and metre) and relentlessly ironic:

Dum fortuna tibi prosperior, dum placidus, Lyce,

Aspiraret amor, dum facies aemula liliis

Certaretque rosis; deliciis omnibus affluens

Usus te facili est ille tuus Demochares: neque

Nostri te interea cura subiit vel minima, ut fores

Porrectum ante tuas respiceres, et misere Notis

Enectum pluviis in tepido calfaceres sinu.

Nunc postquam Venus et perfuga Amor castra alio movent,

Et rugis faciem longa dies asperat invidis

Dilectamque Lycen Demochares negligit improbus,

Ultro accersimur, ultro expetimur. Scilicet ut satur

Ructet carnem alius, reliquis pascar ego ossium. ${ }^{34}$

[Lyce! While a more prosperous fortune and gentle love were favourable to you, / while your face was rivalling the lilies and competing with the roses, / that Demochares of yours, overflowing with all delights, had easy access to you. / In those days you did not care at all about me, / who was prostrate in front of your door / and tortured by the south wind (Notus),

\footnotetext{
${ }^{31}$ This cliché in linguistic perspective cf. Przybylska 2016, 543-548.

${ }^{32}$ Cf. Salzman-Mitchell 2005, 61.

${ }^{33}$ Cf. Barolini 2006, 107-110. Different interpretative contexts related with Danaids's punishment are often evoked in literary studies, cf. e.g. Milnor 2005, 51-52; Bowlby 2007, 75-100; Janan 2001, 56-68; Caldwell 1993, 75-102.

${ }^{34}$ Kochanowski 1580, $\mathrm{B}_{3}$ r.
} 
the rain-bearer; / you did not care to warm me on your tepid bosom. / And now, when Venus et Amor, the deserter, / have moved their camp elsewhere, / when length of days has made your face rough with nasty wrinkles / and when the perverse Demochares has neglected / his beloved Lyce, you invite me yourself, you need me - that means, he is satiated ad nauseam with meat / and I am supposed to chew the bones left by him]

The addressee, Lyce, ${ }^{35}$ is a woman grown old, who desperately needs a lover and seeks him among the ones she had neglected. The metre of the poem, major Asclepiadean, is the same as in Horace Ad Leuconoem, but the lyrical situation is completely different. Briefly, in Horace, it is him who (most probably) wants sex, while she prefers a conversation. ${ }^{36}$ In Kochanowski we are provided with a dichotomous image of the addressee in the past, when she has been an object of desire, and now, when she can only dream about being one. The language of signs is clear - a typical paraclausithyron setting, a female fortress besieged by the unfortunate lover ignored by his cruel beloved who is sure of her beauty and satisfied in love. Then the floral metaphors from the first part fall like rose petals and expose the truth about the abominable woman. The truth may be represented literally, as the wrinkled face, and also at the figurative level, either as a kind of abandoned bastion which nobody, neither Venus nor Amor will defend, or as nothing but the bones. It means more than a commonplace "just skin and bone" hyperbole; it is deeply immersed in the sexual symbolism of the act of a man eating meat. Moreover, one may think about the old Latin proverb Tarde venientibus ossa [the bones go to all those who come late] ${ }^{37}$ and appreciate Kochanowski's imagery and his keen irony - who would dare to invite guests to a banquet and serve only bones already picked?

And now we can consult the Horatian background of both Kochanowski's poems in Hor. Carm. III. 10 and IV. 13: the paraclausithyron setting, ${ }^{38}$ the change of appearance causing the fleeing of Venus and Cupid, the behaviour inviting human mockeries, and finally the image of a torch turned into ashes:

\section{Importunus enim transvolat aridas \\ quercus et refugit te quia luridi \\ dentes, te quia rugae \\ turpant et capitis nives.}

Quo fugit Venus, heu, quove color, decens

quo motus? Quid habes illius, illius,

${ }^{35}$ On the poem and its Horatian model (and vernacular parallels) cf. also Hobot 2016, 269-280.

${ }^{36} \mathrm{Cf}$. Anderson 1999, 41-43.

${ }^{37} \mathrm{Cf}$. Stone 2009, 247.

${ }^{38}$ Cf. Hor. Carm. III 10 1-4: "Extremum Tanain si biberes, Lyce, / saevo nupta viro, me tamen asperas / porrectum ante foris obicere incolis / plorares Aquilonibus." ["If you were drinking the waters of the distant Don, Lyce, and married to a barbarous husband, you would still be sorry to make me lie here on your cruel doorstep at the mercy of your neighbours the northern winds," Horace 2000, 89]. 
quae spirabat amores,

quae me surpuerat mihi, ${ }^{39}[11$.

[That demanding god soars over dry oaks. / He flies away from you, your black teeth / your wrinkles, and the snow in your hair. You are ugly / Where has your charm gone? Where is your complexion? / Where is that lovely way of moving? What remains / of the girl, who breathed the breath of love, / who stole me from myself] ${ }^{40}$

We may add that in his Latin verse Kochanowski does not have much to do with male old age. However, when we read his vernacular poetry, we find out some evidence that he was much more indulgent to old men. In an Anacreontic poem from the Trifles [Fraszki 3, 82], quoted below, he uses some figurative descriptions of male sexual strength. The first is the garlic metaphor, which may be compared to a similar one (of leeks) in Rabelais: ${ }^{41}$

Do not run away from me, fair young maid;

My heart is not yet old, though my beard is grey;

But even if grey, I'm still without fail:

Garlic has a white head, but a green tail. ${ }^{42}$ [11. 5-8]

And now something in a decidedly less frivolous tone. Thomas Treter (1347-1610), more famous as an engraver than as a poet, composed a series of panegyric poems to the memory of Stanislaus Hosius after the cardinal's death. I have chosen an ode in which Treter presents a twofold image of old age - of Hosius, who is the main hero of the entire Theatrum virtutum ${ }^{43} \ldots$, and that of the poet's father, who is the addressee of the poem. ${ }^{44}$ Hosius's old age is meant as an example for the old father:

Laudande multis nominibus pater,

Colende nobis perpetuo senex,

Magnum senectutis levamen

Inspicias Hosii senectam $[11.1-4]^{45}$

[Father, honorable for many reasons / Whom I will respect forever, / In your old age find relief / Looking upon Hosius's senectitude.]

\footnotetext{
${ }^{39}$ Hor. Carm. IV 13 9-13, 17-20.

${ }^{40}$ Horace 2000, 128.

41 "You mock me for my greying hair, but you don't consider that my nature is like the leeks, which we find white on top when its tail's green, straight, and vigorous", Rabelais 1955, 365 .

${ }^{42}$ Lipinski 2001, 11. In the Polish original: "Nie uciekaj przede mną, dziewko urodziwa, / Serceć jeszcze niestare, chocia broad siwa;/ Choć u mnie broda siwa, jeszczem niezganiony, / Czosnek ma głowę białą, a ogon zielony" (Kochanowski 1967, 235).

${ }^{43}$ Treter 1686.

${ }^{44}$ Treter 1686, Q4r-Rr.

${ }^{45}$ Treter 1686, Q4r.
} 
Hosius's old age was 'good' and its only disadvantage was a corporeal weakness:

Sed languor, aetati comes additus,

Sensim per artus progrediens, brevis

Vitae admonebat, iam propinquum

Terminum adesse docens laborum. [11 13-16 $]^{46}$

[But languor, this companion of age, / Filling step-by-step the body's members, / Was a reminder of the brevity of life, / Informing that the end of labours is coming.]

In a paradoxical way Hosius became an athletic champion when his body was extremely feeble. His soul reached the finishing line with steps of virtues, like an Olympic runner in a final burst of speed just before the winning-post ("intendit ut cursum vehementius / metae propinquans vincere qui cupit"). ${ }^{47} \mathrm{He}$ did not fear death knowing that he was morally good.

Treter finds his greatest glory in having supported Hosius in his old age ("nos senis optimi /...molle latus famulante dextra / suffulciebamus"); he regrets that living in Rome he is not able to do it for his own father. He only commends him to God and addresses to him the final admonition, evoking the Horatian semiotic landscape:

Felix senectam ducito candidam,

Permitte Christo cetera, qui simul

Ut iusserit, nec tu meo nec

Ipse tuo prohibebor ore $[11.41-44]^{48}$

[Be happy, continue to live your fortunate old age, / Leave everything else to Christ. When he has ordained a thing, / Neither my prayer will change your fate / nor yours mine.]

Treter is consciously echoing the third stanza of Horace's Soracte Ode:

Permitte divis cetera; qui simul

stravere ventos aequore fervido

deproeliantis, nec cupressi

nec veteri agitantur orni. [11. 9-12 $]^{49}$

[Leave everything else to the gods. As soon as / they still the winds battling it out on the boiling sea, / the cypresses stop waving / and the old ash trees. $]^{50}$

\footnotetext{
${ }^{46}$ Treter 1686, Q4v.

${ }^{47}$ Treter 1686, Q4v.

${ }^{48}$ Treter 1686, Rr.

${ }^{49}$ Hor. Carm. I 9, 9-12.

${ }^{50}$ Horace 2000, 33.
} 
It seems possible that the poet does not understand the message of this stanza as consolation but rather as a suspended death sentence. During the storm of life we are still alive, but a motionless calm corresponds with death. In Treter's poem there resound both Christian trust in God and the humble acceptance of his judgements. We cannot guess who will die first, but whoever it may be, the fact will be irrevocable.

Interplays of Horatian and "neo-Horatian" ideas remain active in later Jesuit Neo-Latin poets. Casimir (Maciej Kazimierz Sarbiewski, 1595-1640) ostensibly borrows from Horace his semiotic landscape of human life. ${ }^{51}$ We can notice it in the ode Ad Publium Memmium (Lyr 2.2). In this context, old age is understood as a "winter" of life and grey hair is compared to snow or hoar-frost:

Quae tegit canas modo bruma valles,

Sole vicinos iaculante montes

Deteget rursum. Tibi cum nivosae

Bruma senectae

In caput seris cecidit pruinis,

Decidet numquam. Cita fugit aestas,

Fugit autumnus, fugient propinqui

Tempora veris.

At tibi frigus, capitique cani

Semper haerebunt; neque multa nardus,

$\mathrm{Nec}$ parum gratum repetita dement

Serta colorem. [11 1-12 $]^{52}$

[The valleys, now, are clad in grey / By winter, when Sol darts his ray / On neighbouring hills, he'll naked lay / As heretofore / But when the winter of thy years / With snow, within thy locks appears, / When hoary frost shall dye your hairs, / It parts no more. / Summer and autumn's quickly gone, / Th'approaching spring will pass as soon / Grey hairs, and chilling cold alone / With thee will stay. $]^{53}$

The cycle of seasons corresponds and to some extent contrasts with that of human life - "the losses of nature can be recovered [...], while for us death is irreversible." ${ }^{54}$ The same applies to old age. The rhythm of seasons, subjectively represented in Horace ("Frigora mitescunt zephyris, ver proterit aestas / Interitura,

${ }^{51}$ Sometimes he does it in an antithetic way, construing some images 'against' Horace, as in Lyr 2. 19, imitating Hor. Carm. I. 23. Not only the lascivious context is changed into religious one (Christ appears as an equivalent of the flirting Chloe, who is in Horace the fawn fleeing from the lyrical "I"), but also the green spring of youth, present everywhere in Horace's ode (Nam seu mobilibus veris inhorruit/ adventus foliis.../ Whether the fluttering leaves of the thorn tree shudder in the wind...' Horace 2000,44), becomes in Casimir the late autumn of older age ("Nam seu prima metum bruma trementibus/ Incussit foliis..."' 'For the autumn has frightened the trembling leaves ...'. Sarbiewski 1892, 70).

${ }^{52}$ Sarbiewski 1892,46.

${ }^{53}$ Sarbiewski 2010, 39.

${ }^{54}$ Ancona 1994, 55. 
simul / Pomifer autumnus fruges effuderit, et mox / Bruma recurrit iners") ${ }^{55}$ is similarly considered or even more "humanized" by Sarbiewski, whose second stanza refers to the year's cycle from "winter perspective", alluding also to human life. Youth and maturity are gone quickly, like last summer and autumn; although the next spring is about to come, it is also to be gone in turn. But the last stage of life remains like a linear path leading only to one end. However, all this imagery is meant chiefly to stress the gnomic admonition:

Una quem nobis dederat iuventus,

Una te nobis rapiet senectus;

Sed potes, Publi, geminare magna

Saecula fama $[113-16]^{56}$

[Thee, whom thy youth hath giv'n today, / At night old age will take away, / Thy time to double, is, to lay / A fame most bright. $]^{57}$

Adapting Horace's images, Sarbiewski uses some Stoic and Neo-Stoic arguments (or rather commonplaces) from Seneca ${ }^{58}$ and others.

As regards Albert Ines, Sarbiewski's younger Jesuit fellow-brother and his imitative, but independent follower, ${ }^{59}$ he engages in multi-level intertextual games with his great predecessor, expressing the same ideas in other words, assuming a melancholy tone and creating a misty-foggy semiotic landscape. His ode 53 (Ad Franciscum Rubium) seems to repeat the message of Sarbiewski's Lyr 2.2:

Qua quisque est genitus die

Illa mortis iter capit $[\ldots]$

Et quidqiuid puero temporis additur,

Vitae detrahitur suae.

Sed (proh!) qui pretium temporis aestimat? $[11.5-6,10-12]^{60}$

[The day of one's birth / is the day of entrance on the path of death [...] / The more time is added to a boy's life / The more is taken away / But alas! Who is able to estimate the value of time?]

He builds on the same Senecan-Aristotelian background: "Cum vitam trahimus, perdimus" ("The longer we live, the more we lose our life"). He does not tell much about senectitude. His reflective poems on human life seem to

\footnotetext{
${ }^{55}$ Hor. Carm. IV 7 9-12.

${ }^{56}$ Sarbiewski 1892, 46.

${ }^{57}$ Sarbiewski 2010, 40.

${ }^{58} \mathrm{Cf}$. Sen. De brev. vit 1.

${ }^{59}$ On this matter cf. Borysowska 2010.

${ }^{60}$ Ines $1655,89$.
} 
suggest allusively that it would be better not to achieve old age at all. Such is the essential message of ode 2, entitled Stoicus Christianus. The art of the poem consists in collecting a series of gnomic maxims in a complex way, through the pun on the words. Discussing the poem we can see clearly that the only long life which matters, the only one which anyone should wish for, is the eternal one; those who fear death seem not convinced of their future heavenly happiness or even do not want it:

Is fatum timeat, cui

Mortis certa suae Mors placuit minus;

Is olim timeat mori,

Cui vixisse diu displicet, is nigram

Parcarum paveat colum,

Qui post fata sacros ducere spiritus

Et vixisse perennius

Nec sperat nec amat... [11. 33-40] $]^{61}$

[Let him fear Fate, / Who would not find delight in death of his death / Let him fear death, / Who does not want to live long; Let him be afraid / Of the black thread of Moirae, / Who does not want nor hope / To live, after his life, / A new, eternal, spiritual life.]

The question of age is linked to a rivalry between pagan and Christian tradition. A true Christian should not follow Homeric Nestor trying to equal him in longevity. There is a better example, a Christian Nestor, the martyr of Thessaloniki, who - as the legend has it - had killed a gladiator (named Lyaeus) during Maximian's reign. ${ }^{62}$ Thus, he merited the rudis (a wooden sword given to gladiator as a sign that he is discharged), and also heavenly felicity. It is the goal of a true athleta Christi:

Non qui Nestoreis solibus aemulas

Implevit Trieterides

Sed qui Nestorea dignus erat rude,

Festis floret adoreis

Aeternoque sibi plaudit in otio [11. 6-10] $]^{63}$

[It is not him, who enters in competition with Nestor / in a number of days of life, / But it is him, who merited Nestor's rudis, / That flourishes in a splendid feast / In the sweetness of eternal quiet]

The image of old age in Polish Neo-Latin poetry of the 16th and 17th century seems to abound in various features. It may be more or less personalized, characterized by some figures as that of a matron, of an Anchises-like father,

\footnotetext{
${ }^{61}$ Ines $1655,7$.

${ }^{62}$ White 2013, 14-15, 103.

${ }^{63}$ Ines $1655,6$.
} 
a Christian "athlete", a ridiculous aged woman in love. It may be also more allusive, gnomic and moralising, but even in the case of such a series of commonplaces we can see certain role-models embedded in the ancient or Christian tradition. The poets often borrow patterns from Horace or Ovid, either combining their language and imagery or transforming their lexical structures and adapting them to some new ideological purposes.

\section{BIBLIOGRAPHY}

\section{Primary sources}

Cicero. Letters and Treatises of Cicero and Pliny. Transl. by E. S. Shuckburgh. 1909. New York. Cochanovius, I. Lyricorum Libellus. 1580. Krakow.

Cochanovius, I. Elegiarum Libri III, Eiusdem Foricoenia sive Epigrammatum Libellus.1584. Krakow.

Horace. Horace for Students of Literature. The 'Ars Poetica' and its Tradition. Ed. by O.B. Hardison, L. Golden. 1995. Gainesville.

Horace. The Complete Odes and Epodes. Transl. by David West. 2000. Oxford.

Ines, A. Lyricorum Centuria I Politicis, Ethicis, Poeticis Axiomatibus ac Problematibus instructa. 1655. Dantisci.

Kochanowski, J. Dzieła polskie. Ed. by J. Krzyżanowski. 1967. Warszawa.

Landino, C. Poems. Transl. By Mary P. Chatfield. 2008. Cambridge, MA.

Treasury of Polish Love: Poems, Quotations and Proverbvs: In Polish and English. Ed., tr. by M. Lipinski et al. 2001. New York.

Rabelais, F. The Histories of Gargantua and Pantagruel. Tr. by J. M. Cohen. 1955. Harmondswork.

Vigilantius Gregorius Samboritanus. Theoresis secunda seu Parentes. 1562. Cracoviae.

Vigilantius Gregorius Samboritanus. Poezje wybrane/Carmina selecta. Ed., tr. by E. Buszewicz. 2011. Warszawa.

Sarbiewski, M. C. Poemata omnia. Ed. by Thomas Wall. 1892. Staraviesiae.

Treter. T: Theatrum virtutum D. Stanislai Hosii, ... per Thomam Treterum ... exhibitum, 1686. Kraków.

Sarbiewski, M.C. : Casimirus Britannicus: English Translations, Paraphrases, and Emulations of the Poetry of Maciej Kazimierz Sarbiewski: Revised and Expanded Edition. Ed. by K. Fordoński, P. Urbański. 2010. London.

Secondary sources

Allen 2006: Allen, G. 2006. Intertextuality. London and New York: Routledge.

Ancona 1994: Ancona R., 1994. Time and the Erotic in Horace's Odes. Durham: Duke University Press.

Anderson 1997: Anderson, W.S. “Commentary.” In: Metamorphoses: Books 1-5. Ed. by W. S. Anderson. Norman:University of Oklahoma Press.

Anderson 1999: Anderson, W. S. 1999. Horace's Different Recommenders of Carpe Diem In C. 1. 4, 7, 9, 11. In Why Horace? A Collection of Interpretations. Ed. by W. Anderson, 37-43. Wauconda: Bolchazy-Carducci.

Baldick 1990: Baldick, Ch. 1990. The Concise Dictionary of Literary Terms. Oxford: Oxford University Press.

Barolini 2006: Barolini, T. 2006. Dante and the Origins of Italian Literary Culture. New York: Fordham University Press. 
Borowicz 2016 (V): Borowicz, S. 2016. "W odwróconym świecie obrazu: wiek XVI (sztuki piękne)." In Anty-Beatrycze: studia nad kulturowa historia obrazu pijanej i szalonej staruchy. Ed. by S. Borowicz, J. Hobot-Marcinek, R. Przybylska, 169-254. Kraków: Wydawnictwo Uniwersytetu Jagiellońskiego.

Borysowska 2010: Borysowska, A. 2010. Albert Ines (1619-1658): Jezuicki 'vates Marianus'. Warszawa: IBL PAN.

Bowlby 2007: Bowlby, R. 2007. "Fifty-Fifty. Female Subjectivity and the Danaids." In Freudian Mythologies: Greek Tragedy and Modern Identities. Ed. by R. Bowlby, 75-100. Oxford and NY: Oxford University Press.

Borowicz 2016 (VII): Borowicz, S. 2016. "W stronę realizmu - wiek XVII (sztuki piękne).” In Anty-Beatrycze: studia nad kulturowa historia obrazu pijanej i szalonej staruchy. Ed. by S. Borowicz, J. Hobot-Marcinek, R. Przybylska, 313-378. Kraków: Wydawnictwo Uniwersytetu Jagiellońskiego.

Borowicz, Hobot, Przybylska 2016: Borowicz, S., Hobot-Marcinek, J., Przybylska, R. 2016. AntyBeatrycze: studia nad kulturowa historia obrazu pijanej i szalonej staruchy. Kraków: Wydawnictwo Uniwersytetu Jagiellońskiego.

Buszewicz 2011: Buszewicz, E. 2011. "Preface". In Grzegorz z Sambora / Vigilantius Gregorius Samboritanus, Poezje wybrane/Carmina selecta. Ed. and transl. by E. Buszewicz, 13-69.... Warszawa: Neriton.

Caldwell 1993: Caldwell1, R. S. 1993. "Aeschylus' Suppliants: A Psychoanalytic Study.” In Modern Critical Theory and Classical Literature. Ed. by I. De Jong and J. P. Sullivan, 75-101. Leiden: Brill.

Commager 1962: Commager, S. 1962. The Odes of Horace: A Critical Study. New Haven: Yale University Press.

Chandler 2002: Chandler, D. 2002. Semiotics: The Basics. London: Routledge.

Danielewicz 1975: Danielewicz, J. 1975. "Pejzaż semiotyczny w Pieśniach Horacego.” Eos 63: 297-301.

Eco 1976: Eco, U. 1976. A Theory of Semiotics. Bloomington: Indiana University Press.

Hobot 2016: Hobot-Marcinek, J. 2016. "Dychotomie. Wiek XVI (literatura)." In Anty-Beatrycze: studia nad kulturowa historia obrazu pijanej i szalonej staruchy. S. Borowicz, J. Hobot-Marcinek, R. Przybylska, 255-312. Kraków: Wydawnictwo Uniwersytetu Jagiellońskiego.

Janan 2001: Janan, M. 2001. The Politics of Desire: Propertius IV. Berkeley: University of California Press.

Milnor 2005: Milnor, K. 2005. Gender, Domesticity and the Age of Augustus: Inventing Private Life, Oxford.

Przybylska 2016: Przybylska, R. 2016. "Ta, która wie. Uwagi o kulturowym stereotypie 'pijanej i szalonej staruchy' w świetle danych językowych.” In Anty-Beatrycze : studia nad kulturowa historia obrazu pijanej i szalonej staruchy. S. Borowicz, J. Hobot-Marcinek, R. Przybylska, 539-550. Kraków: Wydawnictwo Uniwersytetu Jagiellońskiego.

Salzman-Mitchell 2005: Salzman-Mitchell, P. B. 2005. A Web of Fantasies: Gaze, Image and Gender in Ovid's Metamorphoses, Columbus. The Ohio State University Press.

Stone 2009: Stone, J.R. 2009. Latin for the Illiterati, Second Edition: A Modern Guide to an Ancient Language. New York-London: Routledge.

Van Leuven 2005: Van Leeuwen, Th. 2005. Introducing Social Semiotic. London: Routledge.

White 2013: White, M. Military Saints in Byzantium and Rus: 900--1500. Cambridge: Cambridge University Press.

Wilkinson 1951: Wilkinson, L.P. 1951. Horace and His Lyric Poetry. Cambridge: Cambridge University Press.

Woodman 1999: Woodman, A. J. 1999. "Horace, Odes II 3." In Why Horace? A Collection of Interpretations. Ed. by William S. Anderson, 117-129, Wauconda: Bolchazy Carducci. 


\section{SEMIOTYKA STAROŚCI W POLSKIEJ POEZJI NOWOŁACIŃSKIEJ. GRZEGORZ Z SAMBORA, KOCHANOWSKI, TRETER, SARBIEWSKI, INES}

Streszczenie

Artykuł jest próbą zanalizowania (zwłaszcza w kontekście występującego w badaniach literaturoznawczych pojęcia „pejzażu semiotycznego”) obrazu starości zawartego w kilku utworach należących do wczesnonowożytnej poezji polsko-łacińskiej. W omawianych tu tekstach z XVI (Jana Kochanowskiego, Grzegorza z Sambora, Tomasza Tretera) oraz XVII w. (Macieja Kazimierza Sarbiewskiego, Alberta Inesa), dostrzeżone zostały klisze retoryczne i stereotypy kulturowe, zakorzenione w archetypowych obrazach sędziwych mężów (np. Anchizesa) i niewiast. Poetyckie wizerunki pobożnych starców są mniej zróżnicowane niż obrazy kobiet - tu bowiem obok pobożnej, gotowej na śmierć matrony pojawia się także stara pijaczka, rozpustnica, zalotnica czy stręczycielka. U poetów jezuickich XVII w. obraz starości wpisany jest w temat ogólnej refleksji nad życiem i przemijaniem. U wszystkich poetów widać intertekstualne gry z autorami starożytnymi, szczególnie z Horacym lub Owidiuszem, co uwidacznia się zwłaszcza w przejmowaniu swoistego (typowego przede wszystkim dla Horacego) sposobu obrazowania (jak np. skojarzenie starczej siwizny i niedowładu z zimowym pejzażem i mrozem). 